\title{
CORONG KABATAKU: MEDIA EFEKTIF PEMBELAJARAN BERHITUNG DI SEKOLAH DASAR
}

\author{
Suci Frisnoiry ${ }^{1}$, Faisal $^{2}$, Naeklan Simbolon ${ }^{2}$ \\ ${ }^{1}$ Jurusan Pendidikan Matematika, Fakultas Matematika dan Ilmu Pengetahuan Alam, Universitas Negeri Medan, \\ Medan, Indonesia \\ ${ }^{2}$ Program Studi Pendidikan Guru Sekolah Dasar, Fakultas Ilmu Pendidikan, Universitas Negeri Medan, Medan, \\ Indonesia \\ *Penulis Korespondensi: sucifrisnoiry@gmail.com
}

\begin{abstract}
Abstrak
Program pengabdian ini bertujuan untuk meningkatkan kompetensi guru dalam menggunakan "Corong Kabataku" sebagai media efektif pada pembelajaran berhitung di Sekolah Dasar (SD), khususnya di Kec. Medan Selayang Kota Medan. Hal ini dilakukan berdasarkan analisis permasalahan yang dialami mitra pada pembelajaran berhitung di SD, antara lain: (1) media yang digunakan guru hanya media gambar saja dan siswa hanya difasilitasi untuk mengamati, (2) guru belum mampu membuat alat peraga sendiri, di mana pada umumnya guru hanya menggunakan media-media yang sudah ada di sekolah dan diperoleh dengan cara dibeli, (3) guru umumnya menggunakan RPP yang langsung diadopsi dari internet tanpa menyesuaikan dengan kondisi di sekolahnya, dan (4) penilaian berhitung umumnya dilakukan berdasarkan hasil saja tanpa disertai dengan penilaian proses penemuannya. Solusi terhadap permasalahan yang dihadapi mitra di atas antara lain: (1) pendampingan penyusunan Rencana Pelaksanaan Pembelajaran (RPP), (2) Pendampingan manajemen kelas, (3) pendampingan penilaian otentik, (4) pendampingan cara membuat media "Corong Kabataku", (5) pendampingan cara menggunakan media "Corong Kabataku", (6) simulasi dalam bentuk lesson study, (7) open class/real teaching penggunaan media "Corong Kabataku" pada pembelajaran berhitung, (8) monitoring dan evaluasi, dan (9) tindak lanjut. Berdasarkan hasil analisis, rata-rata tingkat keberhasilan program pengabdian adalah $88,5 \%$ dengan kualifikasi Sangat Baik (SB).
\end{abstract}

Kata kunci: Corong Kabataku; Berhitung; Sekolah Dasar.

\begin{abstract}
This service program aims to improve teacher competency in using the "Corong Kabataku" as an effective media in learning to count in elementary schools, especially in Kec. Medan Selayang, Medan. This is done based on an analysis of the problems experienced by partners in numeracy learning in elementary schools, including: (1) the media used by teachers are only drawing media and students are only facilitated to observe, (2) teachers have not been able to make their own teaching aids, where at teachers generally only use media that are already in school and are obtained by purchase, (3) teachers generally use lesson plans that are directly adopted from the internet without adjusting to the conditions in their schools, and (4) numeracy assessments are generally based on results alone without being accompanied with an assessment of the process of discovery. Solutions to the problems faced by the partners above include: (1) assistance in preparing Learning Implementation Plans (RPP), (2) Classroom management assistance, (3) authentic assessment assistance, (4) assistance in how to create a "Corong Kabataku" media, ( 5) mentoring how to use the "Corong Kabataku" media, (6) simulations in the form of lesson studies, (7) open class / real teaching use of the "Kabataku Funnel" media in numeracy learning, (8) monitoring and evaluation, and (9) actions continued. Based on the results of the analysis, the average success rate of service programs is $88.5 \%$ with Very Good qualifications.
\end{abstract}

Keywords: Corong Kabataku; Counting; Elementary School.

\section{PENDAHULUAN}

Faktor penentu kesuksesan proses pembelajaran di kelas sangat tergantung pada kemampuan guru dalam merancang desain pembelajaran. Desain pembelajaran yang dimaksud terdiri dari: perencanaan, pelaksanaan, dan penilaian. Kemampuan guru dalam merencanakan pembelajaran berpengaruh besar terhadap pelaksanaan dan penilaian. Demikian juga pelaksanaan, sangat perpengaruh pada penilaian karena penilaian meliputi proses dan hasil. Pelaksanaan pembelajaran yang baik tentunya akan menghasilkan hasil belajar yang berbanding lurus pula. Hal yang diungkapkan bersesuaian dengan pernyataan yang menyatakan bahwa salah satu faktor yang penting untuk mencapai 
tujuan pendidikan adalah proses pembelajaran yang dilakukan, sedangkan salah satu faktor penting untuk efektivitas pembelajaran adalah faktor evaluasi baik terhadap proses maupun hasil pembelajaran (Widyoko, 2009:1). Paparan tersebut mengisyaratkan bahwa pentingnya kompetensi guru dalam menciptakan pembelajaran yang berkualitas dalam setiap pembelajaran di kelas.

Pembelajaran di kelas-kelas awal SD umumnya terfokus pada 3 aspek, yaitu membaca, menulis, dan berhitung. Di antara 3 aspek yang dikemukakan, pembelajaran berhitung merupakan pembelajaran yang perlu mendapat perhatian khusus di antara 2 aspek lainnya. Penyebabnya adalah sulitnya pemahaman konsep berhitung di SD oleh sebagian besar siswa karena kurang mampunya guru dalam menciptakan kualitas pembelajaran yang efektif. Perlu dikatahui bahwa, suksesnya pembelajaran berhitung sangat tergantung dengan kemampuan guru dalam mengembangkan desain pembelajaran berhitung itu sendiri.

Kegiatan berhitung dalam konteks yang sederhana telah dikenalkan sebelum siswa memasuki usia SD. Baik siswa prasekolah maupun SD menjadikan hitungan sebagai kegiatan matematika awal anak. Konsep dasar dari berhitung adalah sistem angka dan jumlah (hitungan) yang merupakan dasar dari sistem matematika. Akan tetapi, pembelajaran berhitung bukanlah suatu yang mudah dilakukan di SD. Banyak siswa mengalami kesulitan dalam belajar matematika salah satunya karena matematika memiliki sifat yang abstrak (Fatmawati, 2014:336).

Upaya menciptakan proses pembelajaran berhitung yang efektif di SD dapat dilakukan dengan menggunakan media berupa alat peraga yang bisa diutak-atik oleh siswa. Beberapa alasan yang dikemukakan tentang pentingnya alat peraga sebagai media efektif pembelajaran berhitung yaitu: (1) Kemampuan fiksatif, artinya dapat menangkap, menyimpan, dan menampilkan kembali suatu obyek atau kejadian. Dengan kemampuan ini, obyek atau kejadian dapat digambar, dipotret, direkam, difilmkan, kemudian dapat disimpan dan pada saat diperlukan dapat ditunjukkan dan diamati kembali seperti kejadian aslinya. (2) Kemampuan manipulatif, artinya media dapat menampilkan kembali obyek atau kejadian dengan berbagai macam perubahan (manipulasi) sesuai keperluan, misalnya diubah ukurannya, kecepatannya, warnanya, serta dapat pula diulang-ulang penyajiannya. (3) Kemampuan distributif, artinya media mampu menjangkau audiens yang besar jumlahnya dalam satu kali penyajian secara serempak, misalnya siaran TV atau Radio (Inawati, 2011:4-5). Oleh sebab itu, sebagai suatu kesatuan yang utuh dengan desain pembelajaran, kemampuan guru dalam mengembangkan media atau alat peraga yang efektif dalam pembelajaran berhitung mutlak diperlukan.

Berdasarkan hasil wawancara dan observasi di SD AlIkhlas Kec. Medan Selayang khususnya pada pembelajaran berhitung diperoleh fakta bahwa pelaksanaan pembelajaran berhitung di kelas belum berjalan secara efektif dan belum mencapai hasil yang maksimal. Beberapa hal yang ditemukan antara lain: (1) pembelajaran masih monoton sehingga siswa terlihat bosan dalam pembelajaran, (2) RPP yang dirumuskan belum menunjukkan berorientasi pada aktivitas, (3) media yang digunakan kurang efektif dan kurang menantang digunakan dalam pembelajaran berhitung, dan (4) penilaian yang dilakukan belum berorientasi pada penilaian otentik di SD. Secara rinci, permasalahan yang diungkapkan dapat dijelaskan sebagai berikut.

\section{1) Proses Pembelajaran}

Proses yang dilaksanakan dalam pembelajaran berhitung masih menggunakan metode konvensional. pembelajaran masih berpusat pada guru. Sementara siswa hanya dikondisikan pada posisi pendengar pasif. Kondisi yang demikian memberikan isyarat bahwa proses pembelajaran berhitung di SD belum terlaksana secra optimal. Padahal, pembelajaran berhitung hendaknya dapat melibatkan siswa secara aktif dalam memahami konsep. Pembelajaran berhitung tidak diajarkan melalui penjelasan-penjelasan, namun melibatkan siswa secara aktif dalam menemukan. Tidak hanya itu, pengelolaan kelas juga kurang terkontrol dengan baik. Sebagian besar siswa ribut dalam pembelajaran, padahal guru sedang menjelaskan konsep. Dengan demikian, pola manajemen kelas juga belum maksimal.

\section{2) Rencana Pelaksanaan Pembelajaran (RPP)}

Pelaksanaan proses pembelajaran yang diungkapkan sebelumnya ternyata dipengaruhi oleh perencanaan pembelaaran yang dirumuskan. Dalam RPP yang dirumuskan, hampir tidak ditemukan tahapan yang jelas pembelajaran berhitung dalam upaya memahami konsep. Tahapan yang dimunculkan pada RPP berorientasi pada penjelasan-penjelasan dari guru bukan melibatkan siswa. Selain itu, secara format dan komponen yang dimuat dalam RPP ada yang belum lengkap terutama pada deskriptor penilaian. Dengan demikian, RPP yang dirumuskan guru pun masih perlu ditingkatkan.

\section{3) Media Pembelajaran}

Media yang digunakan pada pembelajaran berhitung ketika dilakukan observasi hanya menggunakan kelereng, pipet, dan sempoa. Media yang digunakan ini kurang mempunyai daya tarik dan kurang menantang siswa untuk menemukan. Dengan demikian, media yang digunakan perlu dikembangkan lebih lanjut agar pembelajaran berhitung dapat terlaksana secara optimal di SD. Telah diketahui bersama bahwa berhitung merupakan keterampilan mendasar yang diperlukan dalam setiap segi kehidupan.

\section{4) Penilaian Otentik}

Penilaian yang dilakukan hanya beroriantasi pada hasil. Sementara penilaian proses sedikit terabaikan. Pengambilan keputusan terkait dengan hasil belajar siswa hanya berpatokan pada nilai latihan dalam 
mengerjakan soal. Sementara itu, penilaian proses juga semestinya dilakukan berimbang dengan penilaian hasil. Dengan demikian, penilaian otentik belum terlaksana dengan baik sesuai dengan yang ciri pembelajaran efektif di SD.

Paradigma pembelajaran seperti yang telah dikemukakan, adanya indikasi bahwa pembelajaran aktif yang berbasis aktivitas belum berjalan seperti yang diharapkan (Nasrun, dkk, 2018:672). Hal ini terjadi karena belum mampunya guru merancang perangkat pembelajaran yang berorientasi pada aktivitas, melaksanakan proses pembelajaran dengan menggunakan media pembelajaran efektif, dan melakukan penilaian otentik dalam pembelajaran. Dengan demikian, perlu dilakukan upaya perbaikan peningkatan kulaitas pembelajaran berhitung melalui pendampingan guru dalam merancang, melaksanakan, dan menilai secara otentik pembelajaran berhitung di SD.

\section{METODE PELAKSANAAN}

Metode pelaksanaan kegiatan dilakukan ke dalam beberapa tahap, antara lain: (1) persiapan, (2) pelaksanaan, (3) monitoring dan evaluasi, dan (4) tindak lanjut. Secara sederhana, tahapan kegiatan dapat dilihat pada Gambar 1 berikut.

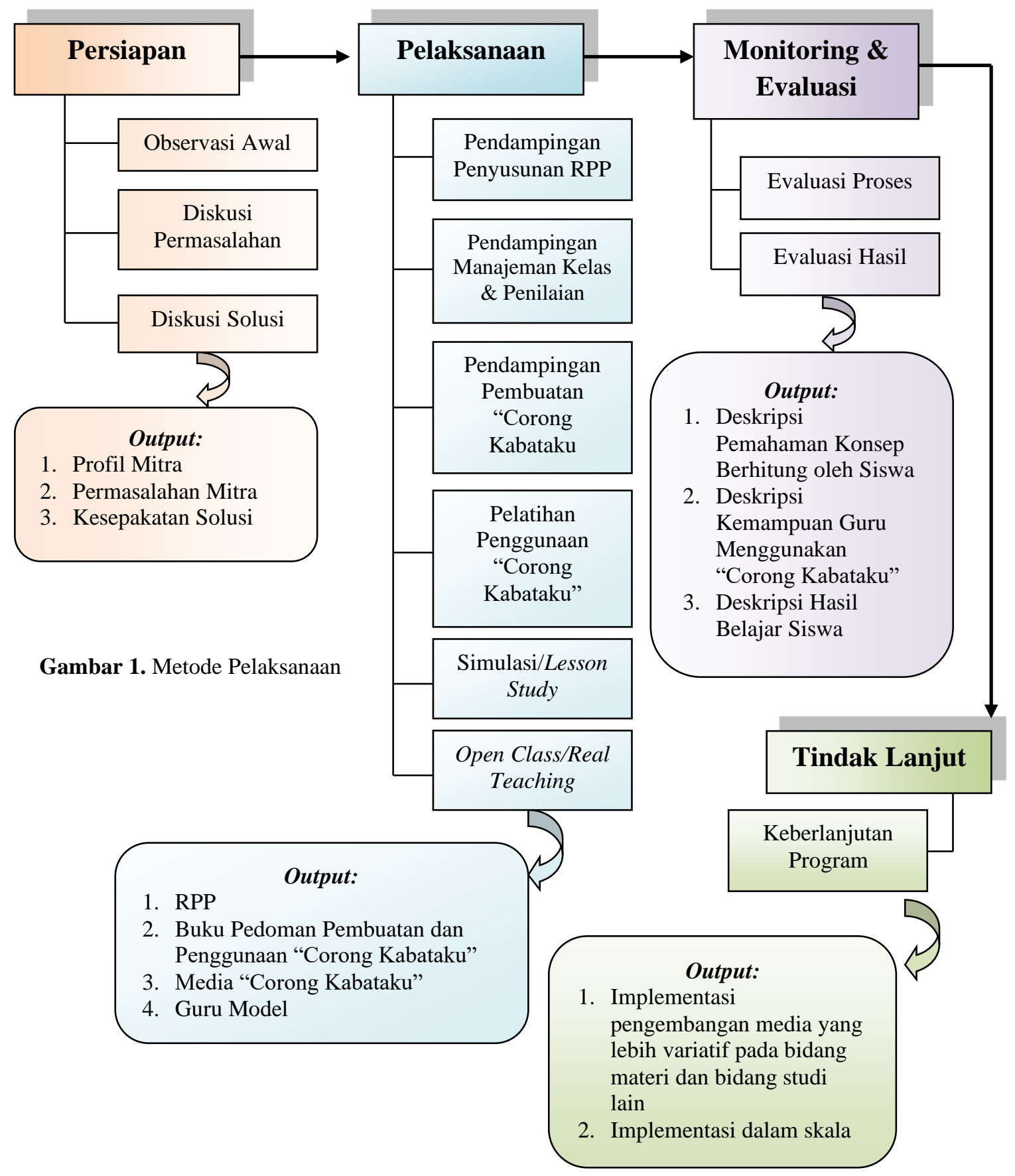


Berdasarkan metode pelaksanaan pada Gambar 3.1, secara rinci setiap tahapan dapat dijelaskan sebagai berikut:

\section{1) Persiapan}

Pada tahap persiapan, dilakukan beberapa kegiatan antara lain:

a. Observasi awal yang bertujuan untuk memperoleh profil sekolah.

b. Diskusi permasalahan yang dihadapi mitra yang bertujuan untuk menentukan permasalahan prioritas mitra yang perlu diberikan pendampingan.

c. Diskusi solusi terhadap permasalahan yang dihadapi yang bertujuan untuk mendiskusikan metode atau bentuk kegiatan dalam mencarikan solusi dari permasalahan.

\section{2) Pelaksanaan}

Kegiatan yang akan dilakukan pada tahap pelaksanaan antara lain:

a. Pendampingan penyusunan RPP yang bertujuan untuk meningkatkan kemampuan guru dalam merancang berhitung menggunakan media "Corong Kabataku".

b. Merancang media "Corong Kabataku" yang bertujuan untuk meningkatkan pemahaman siswa dalam pembelajaran berhitung di SD.

c. Pelatihan penggunaan media "Corong Kabataku" sebagai media efektif dalam pembelajaran berhitung di SD.

d. Simulasi/Lesson Study yang bertujuan untuk melihat kemampuan guru dalam mengajar menggunakan media "Corong Kabataku" dan memberikan masukan terhadap kekurangan guru ketika simulasi.

e. Open Class/Real Teaching bertujuan untuk melihat efektivitas penggunaan media "Corong Kabataku" dalam pebelajaran berhitung di SD.

\section{3) Monitoring dan Evaluasi}

Beberapa kegiatan yang akan dilakukan pada tahap monitoring dan evaluasi antara lain:

a. Evaluasi proses yang bertujuan untuk memantau dan mengukur efektivitas proses pelaksanaan pendampingan yang dilakukan dilihat dari 2 (dua) hal, antara lain: (1) deskripsi pemahaman siswa terhadap konsep berhitung melalui media "Corong Kabataku", dan (2) deskripsi tingkat pemahaman dan kemudahan guru dalam mengajarkan konsep berhitung menggunakan media "Corong Kabataku".

b. Evaluasi hasil bertujuan untuk melihat dampak dan efektivitas penggunaan media "Corong Kabataku" terhadap peningkatan hasil belajar siswa dalam pembelajaran berhitung di SD.

\section{4) Tindak Lanjut}

Tindak lanjut program merupakan upaya keberlanjutan program dalam upaya meningkatkan hasil kegiatan yang telah diperoleh. Kegiatan ini dilakukan pada materi lain, bidang studi yang lain, dan skala yang lebih luas.

\section{HASIL DAN PEMBAHASAN}

\subsection{Hasil Kegiatan}

Program pendampingan "Desain Teknologi Alat Bantu Corong Kabataku sebagai Media Efektif pada Pembelajaran Berhitung di SD Kecamatan Medan Selayang Kota Medan” dilakukan ke dalam beberapa tahapan, antara lain:

\section{1) Persiapan}

Kegiatan yang dilakukan pada tahap persiapan di antaranya: menentukan jadwal kegiatan, menyiapkan alat dan bahan yang dibutuhkan, menyiapkan materi pendampingan, dan menyiapkan peralatan penunjang, misalnya: infocus, loudspeaker, media perekam, dan alat tulis.

\section{2) Pelaksanaan}

Pendampingan dilakukan pada hari Rabu-Kamis tanggal 17-18 Oktober 2018 di SD Al-Ikhlas Kecamatan Medan Selayang. Peserta yang hadir pada kegiatan ini ada 25 orang terdiri dari: kepala sekolah, guru, pegawai, staf LPM, dan mahasiswa. Pelaksanaan kegiatan secara terstruktur dibagi ke dalam beberapa tahap kegiatan, antara lain:

\section{a. Pendampingan Penyusunan RPP}

Pendampingan penyusunan RPP yang bertujuan untuk meningkatkan kemampuan guru dalam merancang berhitung menggunakan media "Corong Kabataku". Kegiatan penyusunan RPP dilakukan melalui beberapa kegiatan, antara lain: pemaparan materi tentang hakikat RPP (pengertian, prinsip, dan komponen RPP) dan praktik penyusunan RPP. Hasil dari kegiatan ini menunjukkan bahwa guru telah mampu merancang RPP pembelajaran berhitung dengan menggunakan media "Corong Kabataku" dalam pembelajaran berhitung di SD. Secara sederhana, gambaran kegiatan dapat dilihat pada Gambar 2 berikut.

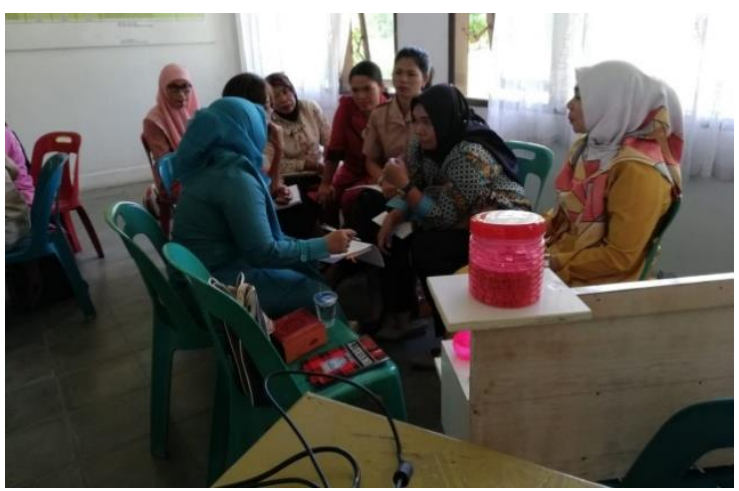

Gambar 2. Kegiatan Merancang RPP.

\section{b. Pendampingan Merancang Media "Corong Kabataku"}

Setelah dilakukan kegiatan merancang RPP, dilakukan pendampingan merancang "Corong Kabataku" sebagai media efektif pembelajaran berhitung di SD. Corong Kabataku yang dirancang diharapkan mampu meningkatkan pemahaman siswa dalam pembelajaran berhitung di SD. Pendampingan yang dilakukan pada tahap ini antara lain: pemaparan materi tentang pengertian "Corong Kabataku” dan kegunaan "Corong Kabataku”, penjelasan tentang alat dan bahan yang 
dibutuhkan, dan pendampingan membuat alat "Corong Kabataku". Secara sederhana, kegiatan merancang media "Corong Kabataku" dapat dilihat pada Gambar 3 berikut.

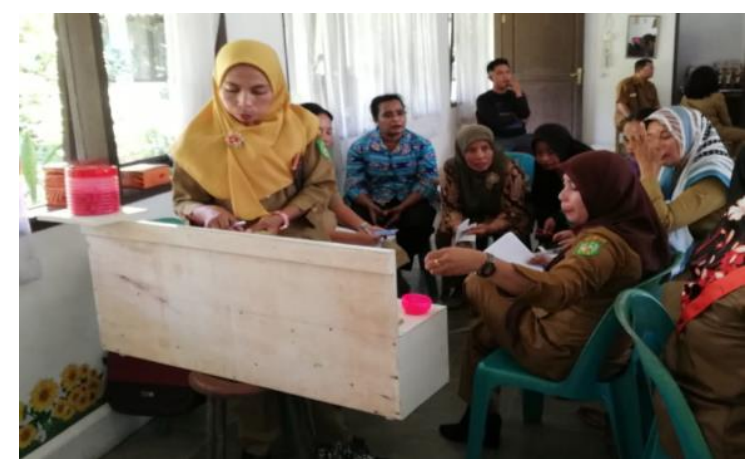

Gambar 3. Kegiatan Merancang Media "Corong Kabataku".

\section{c. Pendampingan Penggunaan Media "Corong Kabataku"}

Kemampuan yang terpenting dari kegiatan ini adalah guru mampu menggunakan media "Corong Kabataku" secara efektif dalam pembelajaran berhitung di SD. Upaya yang dilakukan pada tahap ini adalah pemaparan materi tentang cara penggunaan alat tentang penamaman konsep perkalian, konsep pembagian, konsep penjumlahan, dan konsep pengurangan. Berdasarkan kegiatan yang dilakukan, guru dapat memahami penggunaan "Corong Kabataku" dalam pembelajaran berhitung terutama dalam menanamkan konsep perkalian, pembagian, penjumlahan, dan pengurangan secara efektif. Gambaran sederhana kegiatan pendampingan penggunaan media "Corong Kabataku” dapat dilihat pada Gambar 4 berikut.

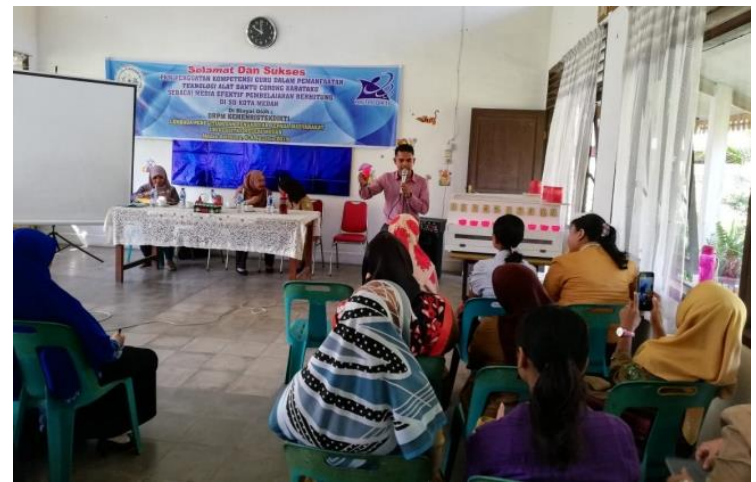

Gambar 4. Suasana Penjelasan Penggunaan Media "Corong Kabataku".

\section{d. Simulasi/Lesson Study Penggunaan Media "Corong Kabataku"}

Simulasi/Lesson Study yang bertujuan untuk melihat kemampuan guru dalam mengajar menggunakan media "Corong Kabataku" dan memberikan masukan terhadap kekurangan guru ketika simulasi. Para guru diminta tampil bergantian dalam melaksanakan proses pembelajaran berhitung menggunakan media "Corong Kabataku" di SD. Melalui simulasi yang dilakukan, para guru memperoleh masukan dan saran yang sangat berharga dalam meningkatkan kemampuan mengajar untuk tahap selanjutnya terutama dalam hal pembelajaran berhitung di SD. Berdasarkan pendampingan yang dilakukan terlihat bahwa kompetensi dan kepercayaan diri guru meningkat dalam menanamkan konsep perkalian, pembagian, penjumlahan, dan pengurangan di SD. Secara sederhana, gambaran simulasi pembelajaran dapat dilihat pada Gambar 5 berikut.

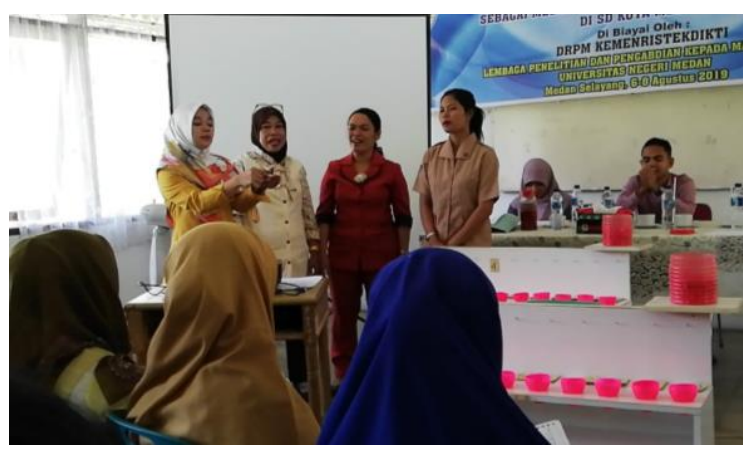

Gambar 5. Simulasi Pembelajaran.

\section{3) Monitoring dan Evaluasi}

Telah dijelaskan sebelumnya pada metode pelaksanaan kegiatan, bahwa tahap evaluasi dan refleksi merupakan penilaian terhadap keberhasilan program pengabdian yang telah dilaksanakan. Berdasarkan hasil evaluasi dan refleksi diperoleh gambaran terkait dengan tingkat capaian keberhasilan dan faktor kendala jika program pengabdian yang dilakukan belum berhasil sesuai dengan yang diharapkan. Berdasarkan observasi dan analisis, tingkat keberhasilan program pengabdian dapat dijabarkan seperti pada Tabel 1 berikut.

Tabel 1. Tingkat keberhasilan Program Pengabdian

\begin{tabular}{|c|l|c|l|}
\hline No & \multicolumn{1}{|c|}{ Kegiatan } & $\begin{array}{c}\text { Persentase } \\
\text { Keberhasilan }\end{array}$ & \multicolumn{1}{|c|}{ Kualifikasi } \\
\hline 1 & Praktik Penyusunan RPP & $87 \%$ & Sangat Baik \\
\hline 2 & Merancang Media "Corong Kabataku” & $89 \%$ & Sangat Baik \\
\hline 3 & Menggunakan Media "Corong Kabataku” & $91 \%$ & Sangat Baik \\
\hline 4 & Simulasi/Lesson Study & $87 \%$ & Sangat Baik \\
\hline \multicolumn{2}{r|}{ Rata-rata } & $\mathbf{8 8 , 5 \%}$ & Sangat Baik \\
\hline
\end{tabular}



berikut.
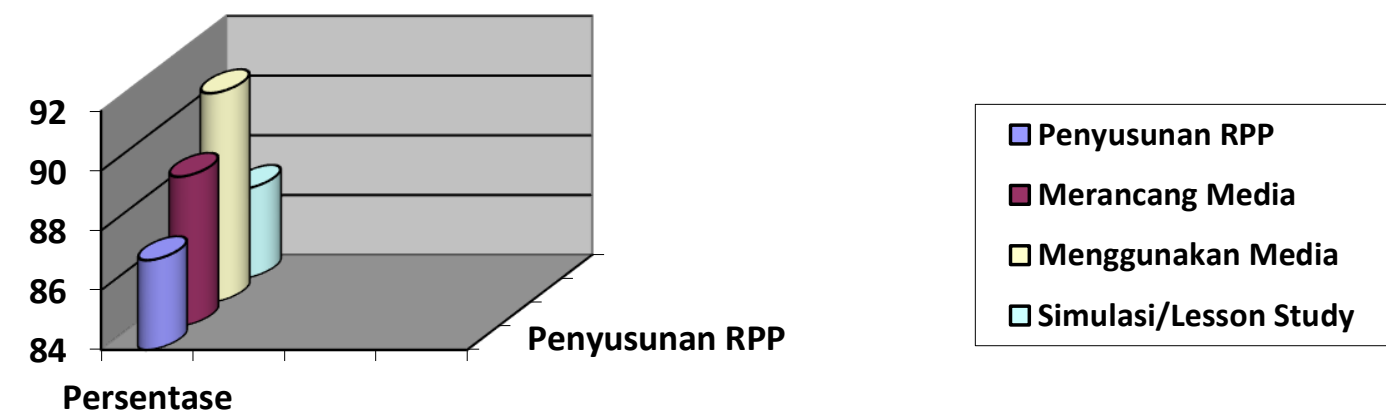

Gambar 6. Tingkat Keberhasilan Program Pengabdian.

Berdasarkan Gambar 6 di atas, diperoleh gambaran bahwa program pengabdian yang dilaksanakan diperoleh rata-rata $88,5 \%$ dengan kualifikasi Sangat Baik (SB). Artinya, program pengabdian yang dilaksanakan sangat baik dan efektif dilaksanakan sebagai upaya meningkatkan kompetensi guru salam menggunakan media "Corong Kabataku" sebagai media efektif dalam pembelajaran berhitung di SD.

\section{4) Tindak Lanjut}

Melihat efektivitas program pengabdian yang dilaksanakan, tindak lanjut program pengabdian yang telah dilaksanakan dirinci sebagai berikut.

a. Menjadikan SD di Kec. Medan Selayang sebagai mitra sasaran (Sekolah Binaan LPPM Unimed) dalam melaksanakan program-program pengabdian pada masa yang akan datang.

b. Menyusun program pengabdian yang sama pada materi lain dalam pembelajaran matematika dengan mengikuti pola: pendampingan menyusun RPP, merancang alat peraga, menggunakan alat peraga, dan simulasi/lesson study, serta dapat dilanjutkan dengan kegiatan open class.

c. Menyusun program pengabdian yang sama pada skala yang lebih luas, yaitu tingkat provinsi Sumatera Utara secara keseluruhan sehingga pembelajaran berhitung yang menjadi kendala bagi guru-guru SD di lapangan dapat diminimalisir secara berkala.

Berdasarkan tindak lanjut yang dipaparkan di atas, diharapkan bahwa LPPM Unimed mampu mengembangkan dan meningkatkan kualitas pembelajaran yang disertai dengan peningkatan kompetensi guru terutama dalam hal merancang alat peraga yang sesuai dengan karakteristik pembelajaran di SD.

\subsection{Pembahasan}

Firman (dalam Faisal, 2018:547) menjelaskan bahwa keberhasilan sebuah program ditandai dengan ciri-ciri sebagai berikut: (a) berhasil mengantarkan peserta mencapai tujuan-tujuan instruksional yang telah ditetapkan, (b) memberikan pengalaman belajar yang atraktif, melibatkan peserta secara aktif sehingga menunjang pencapaian tujuan instruksional, dan (c) memiliki sarana-sarana yang menunjang proses pembelajaran. Selain itu, dijelaskan juga bahwa keberhasilan program ditandai dengan persentase keberhasilan minimal $\geq 75 \%$ pada kategori baik.

Berdasarkan pendapat yang dikemukakan di atas, keberhasilan program pengabdian dapat dijelaskan sebagai berikut.

\section{1) Praktik Menyusun RPP}

Persentase keberhasilan program pengabdian pada tahap menyusun RPP mencapai $87 \%$ dengan kualifikasi Sangat Baik (SB). Artinya, pemahaman dan kemampuan guru dalam menyusun RPP yang berhubungan dengan pembelajaran berhitung menggunakan media "Corong Kabataku" sangat baik dilakukan di SD. hal ini ditandai dari tingkat pemahaman guru dan penilaian terhadap produk RPP yang dihasilkan ketika pendampingan.

\section{2) Merancang Media "Corong Kabataku"}

Persentase yang diperoleh ketika pendampingan merancang media "Corong Kabataku" mencapai 89\% dengan kualifikasi Sangat Baik (SB). Artinya, ketika diberikan pendampingan merancang media, guru mampu dengan sangat baik merancangnya. Hal ini ditandai dari pemahaman guru dalam membuat dan tingkat kebenaran produk yang dihasilkan.

\section{3) Menggunakan Media "Corong Kabataku"}

Tindak lanjut dari produk yang dihasilkan adalah kemampuan guru dalam menggunakannya. Persentase keberhasilan program pengabdian pada tahap ini mencapai $91 \%$ dengan kualifikasi Sangat Baik (SB). Artinya, guru sangat baik dan sangat paham bagaimana cara menggunakan media "Corong Kabataku" dalam pembelajaran berhitung di SD. 


\section{4) Simulasi/Lesson Study}

Hal yang terpenting dari kegiatan ini adalah kemampuan guru menggunakan alat/media "Corong Kabataku" dalam pembelajaran yang sesungguhnya. Upaya yang dapat dilakukan untuk mengukur ketercapaian ini adalah dengan melakukan simulasi/lesson study penggunaan media "Corong Kabataku" dalam pembelajaran. Melalui kegiatan ini, guru memperoleh masukan dan penyempurnaan penggunaan media "Corong Kabataku" dalam pembelajaran berhitung di SD. Persentase tingkat keberhasilan pada tahap ini mencapai $87 \%$ dengan kualifikasi Sangat Baik (SB). Artinya, guru telah mampu dengan sangat baik mensimulasikan pembelajaran menggunakan media "Corong Kabataku" dalam pembelajaran berhitung di SD.

\section{SIMPULAN}

Berdasarkan program pengabdian yang dilaksanakan, diperoleh simpulan sebagai berikut: (1) guru telah mampu merancang RPP yang berhubungan dengan penggunaan media "Corong Kabataku" dalam pembelajaran berhitung di SD, (2) guru telah mampu merancang dan menggunakan media "Corong Kabataku" secara mandiri sebagai upaya peningkatan kompetensi terutama dalam hal penggunaan media efektif dalam pembelajaran di SD, dan (3) guru telah mampu dengan sangat baik mensimulasikan penggunaan media "Corong Kabataku" sebagai media efektif dalam pembelajaran berhitung di SD. Dengan demikian, program pendampingan yang dilaksanakan dalam bentuk "Desain Teknologi Alat Bantu "Corong Kabataku" sebagai Media Efektif dalam Pembelajaran Berhitung di SD Kec. Medan Selayang Kota Medan" telah berhasil dilaksanakan dengan baik di SD.

\section{UCAPAN TERIMA KASIH}

Penulis mengucapkan terima kasih kepada DRPM Kemenristekdikti yang telah memberikan dana program pengabdian sehingga kegiatan pengabdian ini dapat terlaksana dengan baik. Penulis juga mengucapkan terima kasih kepada LPPM UNIMED yang telah memfasilitasi kegiatan sehingga terlaksana dengan baik.

\section{DAFTAR PUSTAKA}

Faisal, F., Gandamana, A., \& Andayani, T. (2018). Penguatan Kompetensi Guru dalam Pembelajaran Tematik sebagai Upaya Optimalisasi Kurikulum 2013 di SD Kecamatan Deli Tua Kabupaten Deli Serdang. Jurnal Pengabdian Kepada Masyarakat, 24(1), 544-550.

Fatmawati, N. (2014). Peningkatan Kemampuan Berhitung melalui Pendekatan Realistic Mathematic Education. JPUD-Jurnal Pendidikan Usia Dini, 8(2), 325-336.

Inawati, M. (2011). Meningkatkan Minat Mengenal Konsep Bilangan Melalui Metode Bermain Alat Manipulatif. Jurnal Pendidikan, 16, 1-10.

Nasrun, N., Faisal, F., \& Feriyansyah, F. (2018). Pendampingan Model Pembelajaran Inovatif di
Sekolah Dasar Kecamatan Medan Selayang Kota Medan. Jurnal Pengabdian Kepada Masyarakat, 24(2), 671-676.

Widoyoko, E. P. (2009). Evaluasi Program Pembelajaran. Yogyakarta: Pustaka Pelajar. 